\title{
Immunological abnormalities and HLA antigen frequencies in IgA deficient patients with epilepsy
}

\author{
A. F O N T A A, H. J O L LER, F. S K VAR I L, A N D P. G R OB \\ From the Section of Clinical Immunology, Department of Medicine, University Hospital, Zürich, \\ and the Institute for Clinical and Experimental Cancer Research, University of Berne, Switzerland
}

SUMMARY Twenty-three epileptics with constitutional factors for seizures and $\operatorname{low} \operatorname{IgA}$ serum concentrations were studied. Imbalance of the IgG subclasses was often observed, the IgG4 being undetectable in $13(65 \%)$ patients. The percentage of circulating lymphocytes positive for surface immunoglobulins was normal except for slightly increased values for $\operatorname{IgA}$ in six $(28.5 \%)$ patients. Of the epileptics, $48 \%$ showed subnormal proportions of lymphocytes forming spontaneous rosettes. There was a distinct trend for HLA-A2 antigen in the patients tested.

Several earlier reports have dealt with immunological abnormalities in epileptic patients. Low serum levels of $\operatorname{IgA}$ were most often described (Sorrell et al., 1971; Grob and Herold, 1972; Slavin et al., 1974; Aarli and Tönder, 1975; Buckley, 1975; Seager et al., 1975; Aarli, 1976; Kanoh and Uchino, 1976; Masi et al., 1976; Andersen and Mosekilde, 1977). Immune reactions dependent on T-lymphocytes have also been shown to be abnormal in some epileptic patients as evidenced by absent delayed-type skin tests to various ubiquitous antigens, diminished lymphocyte stimulation by plant mitogens, and a decrease of circulating T cells (Sorrell et al., 1971; Massimo et $a l ., 1976)$. There are still many questions to be answered, such as whether only certain forms or stages of epilepsy are associated with immunodeficiencies, or whether anticonvulsant drugs especially hydantoins, are mainly responsible for, or at least add to the genesis of, the immunity abnormalities. Little is known about the exact nature of the immunological defects. We recently reported subnormal serum levels of $\operatorname{IgA}$ in 20$25 \%$ of patients with epilepsy characterised by the presence of constitutional factors for seizures, most of them being treated with hydantoins. In contrast IgA deficiency was never encountered in epileptics whose disease was thought to be secondary to traumatic, infectious, or metabolic

Supported by the Swiss National Science Foundation (Grant number 3.077-0.76).

Address for reprint requests: Dr A. Fontana, Section of Clinical Immunology, Department of Medicine, University Hospital, Zürich, Switzerland.

Accepted 14 February 1978 events even when comparable doses of hydantoins were given (Fontana et al., 1976; Ariizumi et al., 1977). Further studies showed that if there is one IgA deficient epileptic member in a family in whom the disease is clustered, $85 \%$ of all other epileptics of the same family have low serum IgA, including some patients without hydantoin medication (Fontana et al., 1978). Thus the association of low serum $\operatorname{IgA}$ and epilepsy seems to be consistent at least in some groups of patients.

In order to characterise further the nature of the immunological abnormality in IgA deficient epileptics, some additional parameters were tested.

\section{Patients and methods}

Twenty-three patients were studied from a group of $52 \mathrm{IgA}$ deficient epileptics described in previous studies (Fontana et al., 1976, 1978). The only additional selection criterion was the willingness of these patients for further collaboration. Sixteen IgA deficient epileptics studied were members of 12 families in whom the disease was clustered (group A). The other seven patients included belonged to families with no other epileptic members. They showed clinical and electroencephalographic features generally accepted for constitutional factors (group B).

The following tests were performed. The serum concentrations of $\operatorname{IgA}$, IgG and IgM were estimated by radial immunodiffusion (partigen plates, Behring). Sera with IgA levels below $0.3 \mathrm{mg} / \mathrm{ml}$ were tested further by the low concentration 
immunoplates (LC-partigen plates, Behring). A semiquantitative estimation of serum levels of the IgG subclasses was performed in 21 patients by immunoelectrophoresis and by double diffusion methods, using monospecific anti-IgG 1-4 as described elsewhere (Skvaril, 1972). Each patient's blood was examined for mononuclear cells carrying surface immunoglobulin according to current techniques using commercial, not trypsin-treated, antisera (Behring); the details were described by Zortea-Caflisch et al., 1975. Spontaneous rosette formation was tested on peripheral mononucleated cells harvested above a Ficoll-Hypaque-gradient and incubated with sheep red blood cells according to current techniques. HLA antigens were determined using the standard NIH two-stage lymphocytotoxicity method. The antisera were kindly provided by the Swiss reference laboratory for tissue typing (Dr M. Jeannet, Geneva), and the tests were performed in the immunology haematology laboratory of our department by $\mathrm{Dr}$ A. von Felten. The control subjects consisted of 1,765 healthy blood donors, living in Switzerland. The overall frequencies of the HLA antigens of patients were compared with those of the control subjects (Jeannet et al., 1977) using Fisher's exact test.

\section{Results}

Detailed data are given in Tables 1,2 , and 3. Of the 23 individuals tested, 13 were males and 10 females with an average age of 19 years. Five patients had not taken hydantoins for at least three years before testing. In three out of 23 patients tested, the average serum IgA levels were below the limit of detection $(<0.05 \mathrm{mg} / \mathrm{ml})$. In the other 20 patients the IgA level was lower than $0.6 \mathrm{mg} / \mathrm{ml}$, a limit well below the mean $-2 \mathrm{SD}$ value $(2.4-1.6 \mathrm{mg} / \mathrm{ml})$. In most patients IgA was the only immunoglobulin class decreased, except in three individuals in whom one or two other immunoglobulin classes were also low.

Nineteen of 21 patients showed imbalance of one or more IgG subclasses. Diminution of serum IgG4 below the limit of detection was the most common abnormality and was seen in $13(65 \%)$ of the 21 epileptics tested. In two patients the absence of IgG4 from the serum was accompanied by decreased IgG1 or IgG2 respectively, and in three others by simultaneous elevation of serum IgG1 and IgG3.

The blood lymphocytes of 21 of the 23 patients were tested for surface-bound immunoglobulins. The percentage of IgA ( $\alpha$-heavy chain) positive cells was normal in 16 individuals $(67 \%)$. It was slightly increased above the mean +2 SD limit of $6 \%$ in six patients $(28.5 \%)$. The percentage of cells positive for Ig when using a polyvalent antiIg serum and of those cells staining with antisera against $\gamma^{-}$or $\mu$-heavy chain, $\lambda$ - or $\kappa$-light chain, never surpassed the mean +2 SD limit.

Table 1 Serum immunoglobulin concentration and IgG subclass imbalances in patients with epilepsy and IgA deficiency

\begin{tabular}{|c|c|c|c|c|c|c|c|c|c|c|}
\hline \multirow{2}{*}{$\begin{array}{l}\text { Group } \\
\text { A }\end{array}$} & $\begin{array}{l}\text { Patient } \\
\text { number }\end{array}$ & $\begin{array}{l}\text { Age } \\
(y r)\end{array}$ & $\frac{\operatorname{Sex}}{\mathrm{M}}$ & $\begin{array}{l}\text { Hydantoins } \\
+\end{array}$ & \multicolumn{3}{|c|}{ 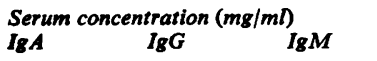 } & \multicolumn{2}{|c|}{$\begin{array}{l}\text { Abnormalities of } \\
\text { IgG4 IgGI-3 }\end{array}$} & Concomitant disorders \\
\hline & $\begin{array}{r}1 \\
2 \\
3 \\
4 \\
5 \\
6 \\
7 \\
8 \\
9 \\
10 \\
11 \\
12 \\
13 \\
14 \\
15 \\
16\end{array}$ & $\begin{array}{r}7 \\
8 \\
6 \\
15 \\
16 \\
12 \\
16 \\
30 \\
13 \\
8 \\
25 \\
10 \\
4 \\
4 \\
26 \\
30\end{array}$ & $\begin{array}{l}\mathbf{M} \\
\mathbf{M} \\
\mathbf{M} \\
\mathbf{F} \\
\mathbf{M} \\
\mathbf{M} \\
\mathbf{M} \\
\mathbf{F} \\
\mathbf{M} \\
\mathbf{F} \\
\mathbf{M} \\
\mathbf{M} \\
\mathbf{M} \\
\mathbf{F} \\
\mathbf{F}\end{array}$ & $\begin{array}{l}+ \\
+ \\
+ \\
+ \\
+ \\
+ \\
+ \\
+ \\
+ \\
+ \\
+ \\
- \\
- \\
-\end{array}$ & $\begin{array}{l}0.1 \\
0.2 \\
0.2 \\
0.3 \\
0.3 \\
0.3 \\
0.3 \\
0.3 \\
0.4 \\
0.4 \\
0.5 \\
0.05 \\
0.1 \\
0.2 \\
0.2 \\
0.1\end{array}$ & \begin{tabular}{r|}
10.3 \\
14.0 \\
12.9 \\
9.5 \\
8.8 \\
8.5 \\
8.5 \\
11.2 \\
11.7 \\
8.5 \\
10.1 \\
14.3 \\
5.2 \\
2.7 \\
15.3 \\
15.4
\end{tabular} & $\begin{array}{l}1.0 \\
2.6 \\
1.4 \\
0.3 \\
2.0 \\
1.8 \\
1.0 \\
1.7 \\
0.7 \\
0.7 \\
1.3 \\
3.2 \\
0.2 \\
0.4 \\
2.1 \\
1.0\end{array}$ & $\begin{array}{l}\uparrow \\
\downarrow \\
\downarrow \\
\downarrow \\
\downarrow \\
\downarrow \\
\downarrow \\
\text { ND } \\
\text { ND } \\
\downarrow \\
\downarrow \\
\uparrow \\
\downarrow \\
\text { ND }\end{array}$ & $\begin{array}{l}\text { IgG1 } \uparrow \\
\text { IgG1, } 3 \uparrow \\
\text { IgG1 } \downarrow \\
\text { IgG1, } 3 \uparrow \\
\text { ND } \\
\text { ND } \\
\text { IgG1 } \uparrow \\
\text { IgG1 } \downarrow \\
\text { IgG2 } \downarrow \\
\text { ND }\end{array}$ & $\begin{array}{l}\text { Chronic respiratory infection } \\
\text { Chronic respiratory infection } \\
\text { Allergic rhinitis } \\
\text { Chronic respiratory infection }\end{array}$ \\
\hline B & $\begin{array}{l}17 \\
18 \\
19 \\
20 \\
21 \\
22 \\
23\end{array}$ & $\begin{array}{l}35 \\
16 \\
53 \\
17 \\
15 \\
20 \\
54\end{array}$ & $\begin{array}{l}\mathbf{M} \\
\mathbf{F} \\
\mathbf{F} \\
\mathbf{F} \\
\mathbf{F} \\
\mathbf{M} \\
\mathbf{F}\end{array}$ & $\begin{array}{l}+ \\
+ \\
+ \\
+ \\
+ \\
-\end{array}$ & $\begin{array}{l}0.05 \\
0.05 \\
0.4 \\
0.5 \\
0.5 \\
0.2 \\
0.5\end{array}$ & $\begin{array}{l}12.2 \\
16.9 \\
14.5 \\
11.0 \\
11.4 \\
13.2 \\
11.6\end{array}$ & $\begin{array}{l}0.6 \\
1.3 \\
2.9 \\
2.1 \\
2.5 \\
1.6 \\
1.5\end{array}$ & $\begin{array}{l}\downarrow \\
\downarrow \\
\downarrow \\
\downarrow \\
\uparrow\end{array}$ & $\begin{array}{l}\text { IgG1, } 3 \uparrow \\
\text { IgG3 } \uparrow\end{array}$ & $\begin{array}{l}\text { Chronic respiratory infection } \\
\text { Chronic respiratory infection } \\
\text { Rheumatoid arthritis } \\
\text { Chronic respiratory infection } \\
\text { Eczema } \\
\text { Recurrent sinusitis }\end{array}$ \\
\hline \multicolumn{5}{|c|}{$\begin{array}{l}\text { Patients (23): mean value } \pm 1 \text { SD } \\
\text { Control subjects }(100): \text { mean value } \pm 1 \text { SD }\end{array}$} & $\begin{array}{l}0.26 \pm 0.16 \\
2.4 \pm 0.8\end{array}$ & $\begin{array}{l}11.4 \pm 3.6 \\
13.0 \pm 1.8\end{array}$ & $\begin{array}{l}1.4 \pm 0.8 \\
1.2 \pm 0.4\end{array}$ & & & \\
\hline
\end{tabular}

ND = not done; $\downarrow=$ not detectable (for IgG4), clearly decreased (for IgG1-3); $\uparrow=$ clearly elevated. 
Table 2 Lymphocyte characteristics of patients with epilepsy and $\operatorname{Ig} A$ deficiency

\begin{tabular}{|c|c|c|c|c|c|c|c|c|}
\hline \multirow[t]{2}{*}{ Group } & \multirow{2}{*}{$\begin{array}{l}\text { Patient } \\
\text { number }\end{array}$} & \multicolumn{6}{|c|}{ Percentage of cells staining with antisera against } & \multirow{2}{*}{$\begin{array}{l}\text { Percentage } \\
\text { spontaneous } \\
\text { rosettes }\end{array}$} \\
\hline & & $I g$ & a-chain & $\gamma$-chain & $\mu$-chain & $\kappa$-chain & $\lambda$-chain & \\
\hline $\mathbf{A}$ & $\begin{array}{r}1 \\
2 \\
3 \\
4 \\
5 \\
6 \\
7 \\
8 \\
9 \\
10 \\
11 \\
12 \\
13 \\
14 \\
15 \\
16\end{array}$ & $\begin{array}{l}15 \\
12 \\
15 \\
10 \\
13 \\
\text { ND } \\
19.5 \\
13 \\
19 \\
\text { ND } \\
15.5 \\
15.5 \\
17 \\
14.5 \\
18 \\
20\end{array}$ & $\begin{array}{c}1.5 \\
4 \\
2.5 \\
7.5 \\
6 \\
\text { ND } \\
5 \\
3.5 \\
3 \\
\text { ND } \\
3 \\
2 \\
6.5 \\
6 \\
1.5 \\
12\end{array}$ & $\begin{array}{c}6 \\
5.5 \\
7 \\
8 \\
6 \\
\text { ND } \\
9.5 \\
6 \\
8 \\
\text { ND } \\
7.5 \\
7.5 \\
5 \\
9 \\
7 \\
12\end{array}$ & $\begin{array}{c}9 \\
5 \\
7 \\
7 \\
5.5 \\
\text { ND } \\
7.5 \\
5 \\
6 \\
\text { ND } \\
7 \\
6 \\
6 \\
8 \\
8 \\
12\end{array}$ & $\begin{array}{c}12.5 \\
8 \\
8 \\
9 \\
\text { ND } \\
\text { ND } \\
8 \\
6 \\
11.5 \\
\text { ND } \\
10 \\
10 \\
9 \\
11 \\
12.5 \\
12.5\end{array}$ & $\begin{array}{l}6 \\
5.5 \\
5.5 \\
9 \\
\text { ND } \\
\text { ND } \\
8 \\
4 \\
8 \\
\text { ND } \\
6 \\
6 \\
5.5 \\
8 \\
8 \\
8\end{array}$ & $\begin{array}{l}52 \\
26 \\
7 \\
52 \\
25 \\
\text { ND } \\
46 \\
22 \\
57 \\
\text { ND } \\
49 \\
48 \\
23 \\
50 \\
52 \\
31\end{array}$ \\
\hline B & $\begin{array}{l}17 \\
18 \\
19 \\
20 \\
21 \\
22 \\
23\end{array}$ & $\begin{array}{c}17 \\
21 \\
7 \\
19.5 \\
13.5 \\
14.5 \\
11\end{array}$ & $\begin{array}{c}9 \\
11.5 \\
1 \\
4 \\
8 \\
4 \\
6\end{array}$ & $\begin{array}{l}6.5 \\
8 \\
6 \\
7 \\
5.5 \\
6 \\
10\end{array}$ & $\begin{array}{l}7.5 \\
2 \\
2 \\
7 \\
5.5 \\
5.5 \\
7\end{array}$ & $\begin{array}{c}13.5 \\
14.5 \\
3 \\
10 \\
10 \\
10 \\
13.5\end{array}$ & $\begin{array}{l}6.5 \\
7.5 \\
2.5 \\
7 \\
7 \\
5 \\
6.5\end{array}$ & $\begin{array}{r}44 \\
40 \\
32 \\
5 \\
32 \\
13 \\
29\end{array}$ \\
\hline \multicolumn{2}{|c|}{$\begin{array}{l}\text { Patients }(21): \text { mean value } \\
\pm 2 \mathrm{SD} \\
\text { Control subjects }(50): \text { mean } \\
\text { value } \pm 2 \mathrm{SD}\end{array}$} & $\begin{array}{l}15.2 \pm 3.5 \\
18+6\end{array}$ & $\begin{array}{l}5.1 \pm 3.1 \\
3+1.5\end{array}$ & $\begin{array}{l}7.2 \pm 1.6 \\
10+4\end{array}$ & $\begin{array}{l}6.4 \pm 2 \\
5 \quad+2\end{array}$ & $\begin{array}{l}10 \pm 2.6 \\
11+5\end{array}$ & $\begin{array}{l}6.4 \pm 1.5 \\
7+2\end{array}$ & $\begin{array}{l}34 \pm 14.7 \\
45 \pm 5\end{array}$ \\
\hline
\end{tabular}

$\mathrm{ND}=$ not done.

Table $3 H L A$ antigen frequencies in patients with epilepsy and $\operatorname{Ig} A$ deficiency

\begin{tabular}{|c|c|c|c|c|c|}
\hline Group & Specificity & $\begin{array}{l}\mathrm{Pat} \\
\mathrm{Nu}\end{array}$ & $\begin{array}{c}(25) \\
\%\end{array}$ & $\begin{array}{l}\text { Controls } \\
(1765)^{*} \\
\text { Number }\end{array}$ & $\%$ \\
\hline $\mathbf{A}$ & $\begin{array}{r}1 \\
2 \\
3 \\
9 \\
10 \\
11 \\
28 \\
29 \\
w 30 \\
w 31 \\
w 32\end{array}$ & $\begin{array}{r}3 \\
24 \\
2 \\
6 \\
0 \\
1 \\
0 \\
2 \\
0 \\
1 \\
0\end{array}$ & $\begin{array}{r}12 \\
96 \\
8 \\
24 \\
0 \\
4 \\
0 \\
8 \\
0 \\
4 \\
0\end{array}$ & $\begin{array}{r}479 \\
822 \\
483 \\
425 \\
49 \\
222 \\
152 \\
140 \\
90 \\
29 \\
136\end{array}$ & $\begin{array}{r}27 \\
47 \\
25 \\
24 \\
12 \\
13 \\
9 \\
8 \\
5 \\
2 \\
8\end{array}$ \\
\hline B & $\begin{array}{r}5 \\
7 \\
8 \\
12 \\
13 \\
14 \\
18 \\
27 \\
w 15 \\
w 16 \\
w 17 \\
w 21 \\
w 22 \\
w 35 \\
w 40\end{array}$ & $\begin{array}{l}6 \\
6 \\
4 \\
8 \\
2 \\
0 \\
1 \\
3 \\
1 \\
0 \\
0 \\
3 \\
2 \\
2 \\
2\end{array}$ & $\begin{array}{r}24 \\
24 \\
16 \\
32 \\
8 \\
0 \\
4 \\
12 \\
4 \\
0 \\
0 \\
12 \\
8 \\
8 \\
8\end{array}$ & $\begin{array}{r}292 \\
424 \\
333 \\
506 \\
80 \\
92 \\
155 \\
136 \\
221 \\
139 \\
131 \\
106 \\
102 \\
344 \\
168\end{array}$ & $\begin{array}{r}17 \\
24 \\
19 \\
29 \\
5 \\
5 \\
9 \\
8 \\
13 \\
8 \\
7 \\
6 \\
6 \\
20 \\
10\end{array}$ \\
\hline
\end{tabular}

*Jeannet et al. (1977).

The corresponding mean values for each of these parameters differed only insignificantly from controls. Ten $(48 \%)$ of 21 IgA deficient epileptics had subnormal percentages of lymphocytes forming spontaneous rosettes (below the mean -2 SD limit of $34 \%$ ).

HLA-A2 antigen was found in 18 of $19(95 \%)$ unrelated IgA deficient epileptics. When six related patients of our series were included, HLA-A2 antigen occurred in 24 of the $25(96 \%)$ patients tested; the frequency of HLA-A2 antigen in a random Swiss population is $45 \%(P<0.001$, $\chi^{2}=9.79$, relative risk $=23.68$ )

Besides the increased frequency of HLA-A2 antigen the patients appeared to show a trend towards lower frequency for HLA-A3 antigen $(P<0.05)$. Although the frequencies of HLA-A1 and A10 antigens were also decreased in comparison with control subjects, none of these deviations was statistically significant.

In 13 of the 23 IgA deficient individuals (56\%) the following concomitant disorders were recorded in the two years before testing: chronic infections mainly of the upper respiratory tract (10 patients), symptoms like rheumatoid arthritis (three patients), eczema (two patients), urticaria (one patient), and allergic rhinitis (one patient). There was no obvious correlation between a given pattern of immune abnormalities and the concomitant disorders or when comparing patients of group A to group $B$ or patients with or without hydantoins. 


\section{Discussion}

The individuals included in this study represent a narrow selection of epileptic patients. All showed clinical and electroencephalographic features of constitutional factors for seizures and all had low serum IgA. The most striking further abnormality seen in such patients was the diminished serum levels of IgG4 observed in $65 \%$ of our patients. IgG subclass abnormalities similar to those found in our series have not been observed in healthy blood donors. However, a high incidence of a deficiency of serum IgG4 has been described in patients with primary hypogammaglobulinaemia and in their relatives, and in non-epileptic individuals with a selective IgA deficiency (Yount et al., 1970; Morell et al., 1975; Yount, 1975; Van der Giessen et al., 1976). Furthermore, patients with multiple sclerosis and subacute sclerosing panencephalitis also have low or undetectable serum IgG4 levels (Vandvik et al., 1976). In these conditions several lines of evidence point to a relative displacement of IgG4, IgG2, and IgG3 by oligoclonal IgG1 proteins.

The percentages of surface Ig positive cells were normal except in six patients with slightly raised values for $\operatorname{IgA}(\alpha$-chain) positive elements. These findings are in accordance with those of other workers who also found normal or elevated numbers of $\operatorname{IgA}$ positive cells in patients with selective IgA deficiency (Lawton et al., 1972; Buckley, 1975). Our data may add to an earlier observation of twin children who both had epilepsy: one child was under hydantoin medication and had low serum IgA with normal IgA bearing lymphocytes, while the other, who was not being treated with hydantoins, had a normal serum IgA concentration but highly elevated IgA bearing cells (Fontana et al., 1978). Although our data and those from others concerning elevated IgA bearing cells seem to be valid, they are difficult to interpret. According to present knowledge neither true IgG nor IgA receptors exist on B-lymphocytes (Kunkel, 1976), leaving the possibility of augmented numbers of Fc-receptor positive cells, of cytophilic antibodies, of non-IgA surface antigens crossreacting with our anti- $\alpha$-chain antisera, or of other still unclear binding phenomena which would explain our findings in epileptics.

Measurement of the formation of spontaneous rosettes by lymphocytes was the only parameter tested concerning T-cells. Half of our patients showed diminished values. Low levels of circulating T-cells were reported in 14 of 48 epileptic children with normal serum $\operatorname{IgA}$ concentration and diminished phytohaemagglutinin-lymphocyte stimulation was found in 41 of these patients (Massimo et al., 1976). In most of the patients without an associated seizure disorder no T-cell defect was observed (Buckley, 1975; Delespesse et al., 1976). IgA deficiency and thymus abnormalities (also evidenced by low levels of circulating $\mathrm{T}$-cells) are encountered in ataxia telangiectasia (McFarlin et al., 1972; Buckley, 1975 ) and in congenital myasthenia gravis, a disease form beginning in the first years of life with frequent familial clusters (Bundey et al., 1972; Behan et al., 1976).

Until recently the existence of a genetic factor in epilepsy was mainly suggested by the occasional familial disease clustering. At least in $\operatorname{IgA}$ deficient epileptics another argument is now introduced by a possible association with HLA-A2 antigen. Although our data appear to be significant, further patients have to be tested for conformation of an HLA-A2 association. When multiplying the $\chi^{2}$-value by the number of antigens tested (26), as recommended, a $P$ value of 0.13 results. So far most of the known associations between HLA antigens and diseases concern the HLA B-locus. This is also true for another seizure disorder, the Lennox-Gastaut syndrome, for which a significant association with HLA-B7 has been reported (Smeraldi et al., 1975). In 26 patients with selective IgA deficiency but no seizure disorder, significantly increased frequencies of HLA-A and B8 antigens were noted by Ambrus et al. (1977).

Thus, at least when taking into account observations from various authors, IgA deficient individuals without epilepsy seem to represent a different population of patients from those with low serum $\operatorname{IgA}$ and epilepsy as evidenced by discrepant data on T-cell immunity and HLA antigens frequencies. A complicating aspect in the interpretation of our findings, is treatment. Most of the patients reported were taking hydantoins, drugs thought to influence the serum IgA levels in epileptics and possibly T-cell functions (Sorrell et al., 1971; Aarli et al., 1975; Seager et al., 1975). However, our data (Fontana et al., 1978) and those of Seager et al., (1975) of immunodeficiencies in epileptic patients without hydantoins and even without any anticonvulsant medication imply that at least part of the immunological abnormalities observed could be inherent in certain forms of epilepsy. Whether the observed immunological abnormalities are the consequence of an underlying disease without biological significance or whether they represent an important factor in the pathogenesis of epilepsy remains to be studied. 


\section{References}

Aarli, J. A. (1976). Changes in serum immunoglobulin levels during phenytoin treatment of epilepsy. Acta Neurologica Scandinavica, 54, 423430.

Aarli, J. A., and Tönder, O. (1975). Effect of antiepileptic drugs on serum and salivary $\operatorname{IgA}$. Scandinavian Journal of Immunology, 4, 391-396.

Ambrus, M., Hernadi, E., and Bajtai, G. (1977). Prevalence of HLA-A1 and HLA-A8 antigens in selective IgA deficiency. Clinical Immunology and Immunopathology, 7, 311-314.

Andersen, P., and Mosekilde, L. (1977). Immunoglobulin levels and autoantibodies in epileptics on long-term anticonvulsant therapy. Acta Medica Scandinavica, 201, 69-74.

Ariizumi, M., Matsuda, H., Osawa, A., Shihara, H., and Baba, K. (1977). Serum IgA levels in childhood epilepsy. Excerpta Medica, 427, 63.

Behan, P. O., Simpson, J. A., and Behan, W. M. H. (1976). Decreased serum-IgA in myasthenia gravis. Lancet, 1, 593.

Buckley, R. H. (1975). Clinical and immunologic features of selective IgA deficiency. Birth Defects: Original Article Series, 11, 134-142.

Bundey, S., Doniach, D., and Soothill, J. F. (1972). Immunological studies in patients with juvenileonset myasthenia gravis and in their relatives. Clinical and Experimental Immunology, 11, 321332.

Delespesse, G., Gausset, P., Cauchie, C., and Govaerts, A. (1976). Cellular aspects of selective IgA deficiency. Clinical and Experimental Immunology, 24, 273-279.

Fontana, A., Grob, P. J., Sauter, P., and Joller, H. (1976). IgA deficiency, epilepsy, and hydantoin medication. Lancet, 1, 228-231.

Fontana, A., Grob, P. J., and Sauter, R. (1978). Immunoglobulin abnormalities in relatives of $\operatorname{IgA}$ deficient epileptics. Journal of Neurology, 217, 207212.

Grob, P. J., and Herold, G. E. (1972). Immunological abnormalities and hydantoins. British Medical Journal, 2, 561-563.

Jeannet, M., Girard, J. P., Varonier, H. S., Mirimanoff, P., and Joye, P. (1977). HLA antigens in grass pollinosis. Monography Allergy, 11, 6973.

Kanoh, T., and Uchino, H. (1976). Immunodeficiency and epilepsy. Lancet, 1, 860-861.

Kunkel, H. G. (1976). Surface markers of human lymphocytes. Behring Instituts Mitteilungen, 59, 1-10.

Lawton, A. R., Royal A. S., Self, K. S., and Cooper, M. D. (1972). IgA determinants on B-lymphocytes in patients with deficiency of circulating IgA. Journal of Laboratory and Clinical Medicine, 60, 26-33.
McFarlin, D. E., Strober, W., and Waldmann, T. A. (1972). Ataxia telangiectasia. Medicine (Baltimore), 51, 281-289.

Masi, M., Paolucci, P., Perocco, P., and Franceschi, C. (1976). Immunosuppression by phenytoin. Lancet, 1, 860 .

Massimo, L., Pasino, M., Rosanda, C., Tonini, G. P., Negri, M., and Saccomani, L. (1976). Immunological side-effects of anticonvulsants. Lancet, 1, 860.

Morell, A., Skvaril, F., Radl, J., Dooren, L., and Barandun, S. (1975). IgG subclass abnormalities in primary immunodeficiency disease. Birth Defects: Original Article Series, 11, 108-111.

Seager, J., Wilson, J., Jamieson, D. L., Hayward, A. R., and Soothill, J. F. (1975). IgA deficiency, epilepsy and phenytoin treatment. Lancet, 2, 632635.

Skvaril, F. (1972). IgG subclass distribution in 695 myeloma sera. Vox Sang, 23, 546-551.

Slavin, B. N., Fenton, G. M., Laundy, M., and Reynolds, E. H. (1974). Serum immunoglobulin in epilepsy. Journal of the Neurological Sciences, 23, 353-357.

Smeraldi, E., Smeraldi, R., Cazzullo, C. L., Cazzullo, A., Fabio, G., and Canger, R. (1975). Immunogenetics of the Lennox-Gastaut syndrome: frequency of HLA antigens and haplotypes in patients and first-degree relatives. Epilepsia, 16, 699-703.

Sorrell, T. C., Forbes, I. J., Burness, F. R., and Rischbieth, R. H. C. (1971). Depression of immunological function in patients treated with phenytoin sodium. Lancet, 1, 1233-1235.

Van der Giessen, M., Reerink-Brongers, E. E., and Algra-van Veen, T. (1976). Quantitation of IgA classes and $\mathrm{IgG}$ subclasses in sera of patients with variety of immunoglobulin deficiencies and their relatives. Clinical Immunology and Immunopathology, 5, 388-389.

Vandvik, B., Natvig, J. B., and Wiger, D. (1976). IgG1 subclass restriction of oligoclonal IgG from cerebrospinal fluids and brain extracts in patients with multiple sclerosis and subacute encephalitis. Scandinavian Journal of Immunology, 5, 427-436.

Yount, W. J., Hong, R., Seligmann, M., Good, R., and Kunkel, H. G. (1970). Imbalances of gamma globulin subgroups and gene defects in patients with primary hypogammaglobulinemia. Journal of Clinical Investigation, 49, 1957-1966.

Yount, W. J. (1975). Imbalances of IgG subclasses and gene defects in patients with primary hypogammaglobulinemia. Birth Defects: Original Article Series, 11, 99-107.

Zortea-Caflisch, C., Odermatt, B., Rüttner, J. R., and Grob, P. J. (1975). Diagnostische Bedeutung der immunologischen Blutlymphozyten-differenzierung. Schweizerisch Medizinische Wochenzeitschrift, 105, 1805-1814. 